\title{
Analysis of Drought and Flood Disasters During 0-1950AD in the Hexi Corridor, China, Based on Historical Documents
}

\author{
Xia Tang ${ }^{1,2 *}$ and Qi Feng ${ }^{1,2}$ \\ ${ }^{1}$ Key Laboratory of Ecohydrology of Inland River Basin, Chinese Academy of Science, Lanzhou, China, ${ }^{2}$ Northwest Institute of \\ Eco-Environment and Resources, Chinese Academy of Sciences, Lanzhou, China
}

It is important to analyze the characteristics of drought and flood change in an arid area over a long timescale for the evolution of the environment. Historical documents were used to reconstruct a drought and flood grade series for the Hexi Corridor from 0 to 1950 AD. The moving average and wavelet transform processing methods were used to determine the temporal evolution characteristics of droughts and floods, as well as the corresponding relationships with climate change and human activities in the Hexi Corridor after 1000 AD. The results showed the occurrence of eight drought phases (370-410 AD, 790-870 AD, 1050-1150 AD, 1260-1340 AD, 1430-1570 AD, 1710-1770 AD, 1800-1890 AD, and

OPEN ACCESS

Edited by:

Zhuolun $\mathrm{Li}$

Lanzhou University, China

Reviewed by:

Guodong Li,

Henan University, China

Yamin Wang,

Changsha Normal University, China

*Correspondence:
Xia Tang
tangxia@llas.ac.cn

Specialty section:

This article was submitted to Interdisciplinary Climate Studies,

a section of the journal

Frontiers in Environmental Science

Received: 22 September 2021 Accepted: 02 November 2021

Published: 23 November 2021

Citation:

Tang X and Feng Q (2021) Analysis of Drought and Flood Disasters During 0-1950 AD in the Hexi Corridor, China,

Based on Historical Documents.

Front. Environ. Sci. 9:781179.

doi: $10.3389 /$ fenvs.2021.781179
1910-1950 AD), five flood phases (320-360 AD, 1670-710 AD, 1730-1790 AD, 1810-1860 AD, and 1880-1950 AD), and 3 oscillation periods of drought and flood events. Climate change may have been the main factor inducing droughts and floods before $1580 \mathrm{AD}$, whereas human activities may have increased the frequency of droughts and floods after the 16th century. Therefore, quantifying the impacts of natural factors and human activities on droughts and floods can provide important theoretical guidance for the prevention and reduction of future disasters.

Keywords: hexi corridor, drought and flood grade, historical period, reconstruction, climate chang

\section{INTRODUCTION}

Coping with droughts, floods, and extreme hydrological events has been a focus of social concern since the beginning of human civilization. Long-term imbalances between water supply and demand lead to droughts and floods (Kundzewicz and Kaczmarek, 2000) that reflect an extremal process in the natural evolution of the climate (Xing et al., 2013). Extremely high temperatures and heavy rainfall events on the global scale may become frequent at the end of the 21 st century, and the overall economic losses caused by extreme climate events could gradually increase (Field et al., 2012). Consequently, the probability and intensity of storms, floods, and drought events will inevitably increase in different regions. The following goal was set in the 2030 Agenda for Sustainable Development adopted by the United Nations in 2015 to reduce disaster risks: "By 2030, significantly reduce the number of deaths and the number of people affected and substantially decrease the direct economic losses relative to the global gross domestic product caused by disasters, including water-related disasters." (Lv et al., 2015).

Study of the occurrence pattern of extreme climate disaster events on the background of global warming, it is necessary to examine climate events over the long-term climate evolution and analyze 


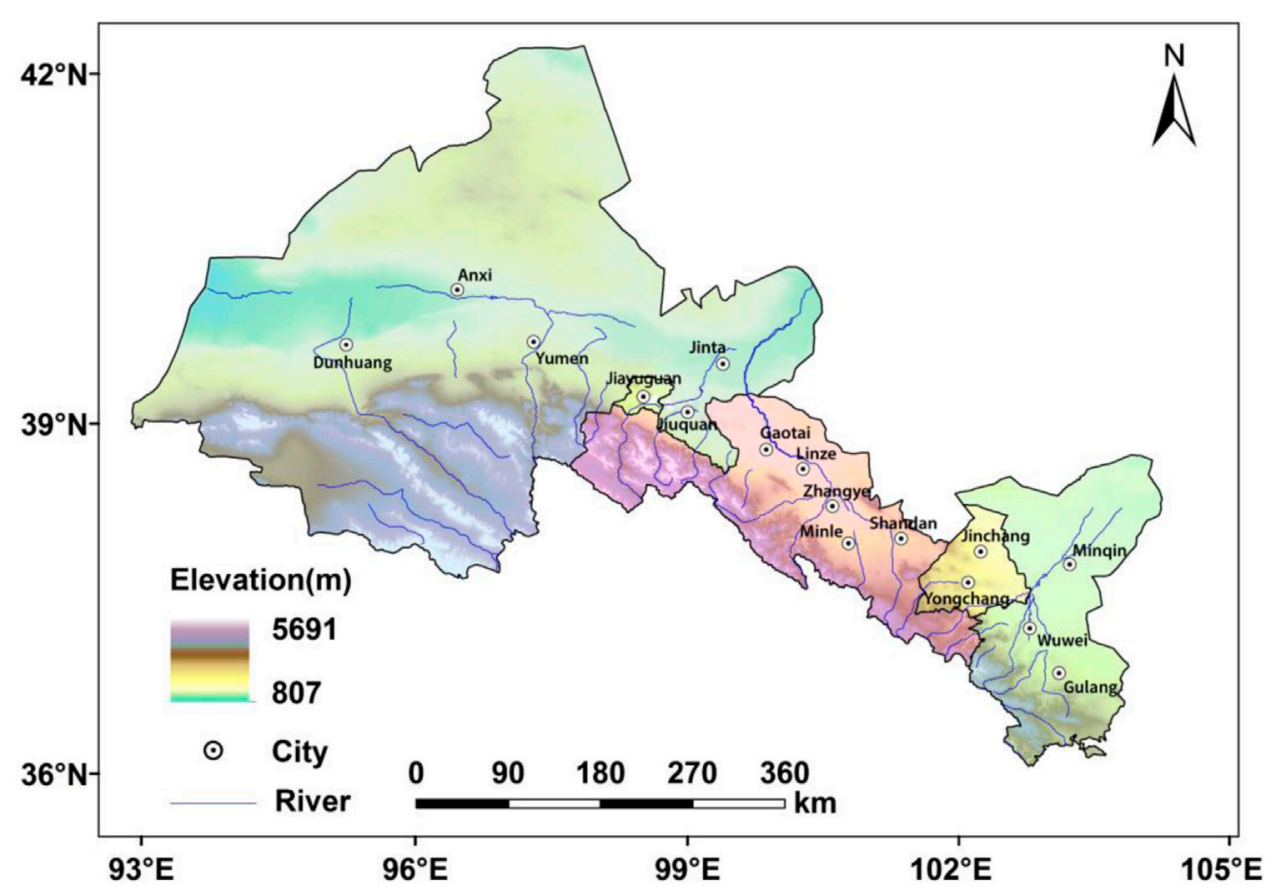

FIGURE 1 | The location of the Hexi Corridor.

the inherent regularity of them. Historical documents have been one of the most important climate records due to their time accuracy, high spatial resolution, and rich information content (Pfister and Wanner, 2002). The Hexi Corridor is located in an inland arid and semiarid climate transition zone in northwestern China with a dry climate and high rainfall variability. Variations in precipitation significantly affect local agricultural production and other aspects of life in the Hexi region and have been the main factor controlling the occurrence of droughts and floods. However, due to the regional differences in the distribution of Chinese historical documents, the previous related studies the climate changes rarely involved the Hexi Corridor of Northwest China. For example, Feng. (1982) compiled climate data from historical documents in the Qilian Mountains and the surrounding areas. Dong et al. (2012) used historical documents to analyze variations in the occurrence of droughts and floods during the Little Ice Age in the Hexi Corridor. Existing studies have mainly been conducted on the Ming and Qing Dynasty periods, for which historical data is relatively abundant. For instance, the consequences of vegetation destruction in the Hexi Corridor have been recorded in historical documents from the Qing Dynasty: 1) The quantity of snow in the Hexi Corridor decreased, the water levels of rivers and streams were low, and the rivers ran dry from time to time. 2) The water level in the rivers was insufficient for irrigation, resulting in drought. 3) The air was dry, and rainfall decreased. (Pan, 2009). However, few studies have been performed on variations in the occurrence of droughts and floods in the Hexi Corridor over the past 2000 years.

A study of the occurrence pattern of extreme climate disaster events against the background of global warming requires an analysis of climate events over a long time scale to discover inherent regularity. Historical documents are one of the most important types of climate records available because of temporal accuracy, a high spatial resolution, and rich informational content (Qian and Zhu, 2002; Ji et al., 2015). Therefore, a variety of historical documents was used to reconstruct a drought and flood series for the Hexi Corridor from 0 to $1950 \mathrm{AD}$ in this study. The wavelet transform was used to analyze the cycle of droughts and floods. The reconstructed drought and flood series was used to discusse the relationship between disasters, human activities and climate change. The results fill in gaps in the understanding of drought and flood characteristics in the Hexi Corridor during 0-1950 AD and lay a foundation for future prevention and mitigation of disasters.

\section{METHODOLOGY}

\section{Study Area}

The Hexi Corridor is located in western Gansu Province $\left(36^{\circ} 46^{\prime}\right.$ $42^{\circ} 49^{\prime} \mathrm{N}, 96^{\circ} 44^{\prime}-104^{\circ} 14^{\prime} \mathrm{E}$ ), with Wushaoling to the east, the intersection of Gansu and Xinjiang to the west, the Qilian Mountains to the south, and the Inner Mongolia Autonomous Region to the north (Figure 1). The corridor spans up to $1,100 \mathrm{~km}$ from east to west over an area of approximately $276,000 \mathrm{~km}^{2}$. Since the four counties of Hexi were established in the Western Han Dynasty (121 BC-111 BC), the Hexi Corridor has been formally included in the political system of the Central Plains Dynasties. The Hexi Corridor was a significant route of China's "Silk Road Economic Belt" between Asia and Europe and an important base for China's grain commodity and metallurgy. 
The Hexi Chorography records show that oasis cultivation, ditch construction, dam construction, and water diversion for irrigation began in the Hexi Corridor over 2000 years ago (Tang and Feng, 2015). The development of large-scale water conservation and excessive logging of surface vegetation accelerated soil salinization and desertification, leading to frequent flood and drought disasters (Xiao and Xiao, 2008; Tang et al., 2014; Sendai, 2015). The Hexi Corridor has a continental monsoon climate characterized by strong winds, dry soil, and frequent droughts in midsummer. Improper farmland water conservation disrupted the ecological balance and affected the temporal and spatial patterns of extreme hydrological processes in inland rivers (Xing et al., 2013).

Four counties, namely, Wuwei, Jiuquan, Zhangye, and Dunhuang, were established in the Hexi Corridor during the Western Han Dynasty. The names of the administrative districts and counties in the Hexi Corridor were subsequently changed occasionally during the Southern and Northern Dynasty and the Sui, Tang, Song, Yuan, Ming, and Qing Dynasties. However, under the current administrative division scheme, the study area mainly corresponds to the historical Hexi Corridor, including the Jiuquan area (the cities of Jiuquan, Yumen, and Dunhuang and Jinta, Guazhou, Subei, and Aksai Counties); the Zhangye area (the cities of Zhangye and Linze, Gaotai, Shandan, Minle, and Sunan Counties); the Wuwei area (the city of Wuwei and Minqin, Gulang, and Tianzhu Counties); and the two prefecture-level cities of Jinchang (Yongchang County, Jinchuan District) and Jiayuguan.

\section{Historical Document Processing}

In ancient times, Chinese governmental agencies generally instituted a special department to compile chorography into an official publication. These typical records are useful for investigating climate change, including natural disasters events and related information (Qian and Zhu, 2002). Data sources of this study are based on "The Chorography of Hexi" (Zhangye Prefectural Committee, 1958) and "Encyclopaedia of China's Meteorological Disasters; Gansu Volume" (Wen and Dong, 2005). Moreover, we further analyzed and verified these collected data with references, including "the History of Disaster and Famine in Northwest China (780 BC-1949 AD) (Yuan, 1994), "the China Meteorological Disaster Encyclopedia: Gansu Fascicule (718 BC-2000 AD)" (Dong et al., 2005), "A Compendium of Chinese Meteorological Records of the Last 3,000 Years" (Zhang, 2000) and "The Atlas of Drought and Flood Distribution over Northwest China in the Past 500 Years" (Bai et al., 2010). These historical records are descriptions of the drought and flood events; thus, they are usually incompleteness and non-continuous. To build a longer record, we synthesized all data sources and then determined a method of replacing missing data. First, we assumed that any year without a flood and drought record was a normal year if the length of missing record was less than 3 years (Chinese Academy of Meteorological Sciences, China Meteorological Administration, 1981). Second, we used the same-year records from other counties that adjoin the Hexi Corridor to identify the missing records.
We selected 0-1950 AD as our study period, spanning approximately 2,000 years. A total of 365 events related to droughts and floods were found. Verbal descriptions of droughts and floods were recorded in the documents, such as "a drought occurred in Ganzhouwei in the summer of the fourth year of the Jingtai Period in the Ming Dynasty (1453 AD)" and "during the first year of the Taiding Period in the Yuan Dynasty (1324 AD), the Heishui River flooded in June, and the rains damaged crops in Ganzhou in September" (Dong et al., 2005). Therefore, this written information was quantitatively analyzed to reconstruct a series of drought and flood grades.

\section{Quantification of Drought and Flood Grades}

The descriptive sentences of droughts and floods recorded in historical documents were comprehensively analyzed. The intensity of a disaster was evaluated based on two aspects, socioeconomics and natural phenomena. The grade classification method of historical droughts and floods of the China Meteorological Administration (Bai et al., 2010) was used to standardize the drought and flood grades obtained from the literature. The records were classified into five grades depending on the severity of the disaster (Table 1): grade 1 denotes flooding, grade 2 denotes partial waterlogging, grade 3 denotes no drought or flood, grade 4 denotes a partial drought, and grade 5 denotes a drought.

\section{Wavelet Analysis}

Morlet first proposed the use of wavelet analysis with a timefrequency multiresolution function for signal processing and analysis in the early 1980s. This method consists of denoising, reconstructing, and extracting signals, such as sound, image, and earthquake signals, to determine the time or frequency domain over which vibration periods of different signals appear. Wavelet analysis is now widely used to study periodic variations in climate and hydrological series (Yuan, et al., 2014; Sang et al., 2013; Ye et al., 2014). Wavelet analysis can clearly reveal local variation characteristics implicit in time series, fully reflect the variations in a system on different timescales, and improve the analysis of the temporal evolution of a series (Abramovich et al., 2000). MATLAB (R2011a) was used in this study to perform a wavelet analysis on the series of drought and flood levels in the Hexi Corridor from 0 to 1950 to determine alternating drought and flood patterns.

\section{RESULTS}

\section{Reconstruction of the Drought and Flood Grade Series}

The aforementioned documents and disaster quantification criterion were used to statistically analyze the series for Hexi drought and flood grades from 0 to $1950 \mathrm{AD}$. A total of 365 droughts or floods of different grades occurred in the Hexi Corridor during this period. Among the 256 droughts, 173 were grade 4, and 83 were grade 5 (Figure 2). Droughts occurred once every seven to 8 years on average. This frequency is slightly higher than that mentioned in the farmer's almanac: "A major drought occurs every 10 years". There were 109 floods of different grades, of which 84 were grade 2 and 25 were grade 
TABLE 1 | Quantification standard for drought and flood grades [1.5].

\begin{tabular}{|c|c|c|c|}
\hline Grade & Quantification criterion & Natural conditions & Socioeconomic aspects \\
\hline 1 (Flood) & $\begin{array}{l}\text { Long-lasting and intense } \\
\text { precipitation: large-scale severe } \\
\text { flooding }\end{array}$ & $\begin{array}{l}\text { Long-lasting heavy rain in the spring and summer; } \\
\text { heavy rain and river flooding in the summer; floods, } \\
\text { storms, and heavy rain; continuous rain lasting from } \\
\text { days to months; upper and lower reaches of river } \\
\text { flooded; rain-damaged crops }\end{array}$ & $\begin{array}{l}\text { People ate each other; the government provided relief to } \\
\text { starving people; countless people and animals drowned; } \\
\text { severe flooding; most people were homeless }\end{array}$ \\
\hline $\begin{array}{l}2 \text { (Partial } \\
\text { waterlogging) }\end{array}$ & $\begin{array}{l}\text { Moderate flood in a single season or } \\
\text { month: regional flooding }\end{array}$ & $\begin{array}{l}\text { Flooding in april; regional floods; heavy/torrential rain; } \\
\text { regional flash floods; sudden mountain torrents } \\
\text { resulting in farmland destruction; long-lasting heavy } \\
\text { rain in autumn resulting in crop damage }\end{array}$ & $\begin{array}{l}\text { Flooding; famine; many people fled their homes; people } \\
\text { who had starved to death were seen everywhere; rice } \\
\text { prices were extremely high }\end{array}$ \\
\hline 3 (Normal) & No droughts or floods & Bumper harvest, rich harvest, a year of plenty & - \\
\hline $\begin{array}{l}4 \text { (Partial } \\
\text { drought) }\end{array}$ & $\begin{array}{l}\text { Moderate drought in a single } \\
\text { season or month: regional drought }\end{array}$ & $\begin{array}{l}\text { Drought in the spring; drought in the autumn; drought } \\
\text { and locust infestation; summer rice yield considerably } \\
\text { lower than usual; little rain for late crops; drought and } \\
\text { plague; drought and famine; drought in the counties of } \\
\text { the Hexi Corridor in the summer and autumn }\end{array}$ & $\begin{array}{l}\text { Drought; land tax collection was halted; famine; many } \\
\text { people fled their homes; people who had starved to } \\
\text { death could be seen everywhere; rice prices were } \\
\text { extremely high }\end{array}$ \\
\hline 5 (Drought) & $\begin{array}{l}\text { Drought lasting for months to } \\
\text { seasons: large-scale severe } \\
\text { drought }\end{array}$ & $\begin{array}{l}\text { Dry rivers and pools; severe drought in the summer } \\
\text { and autumn; no rain from spring to autumn; drought } \\
\text { lasting years, with many people fleeing their homes; } \\
\text { drought from the spring to the autumn, winter drought }\end{array}$ & $\begin{array}{l}\text { People who had starved to death could be seen } \\
\text { everywhere; people ate people; no harvest, famine; the } \\
\text { government provided relief to starving people and } \\
\text { reduced land taxes }\end{array}$ \\
\hline
\end{tabular}

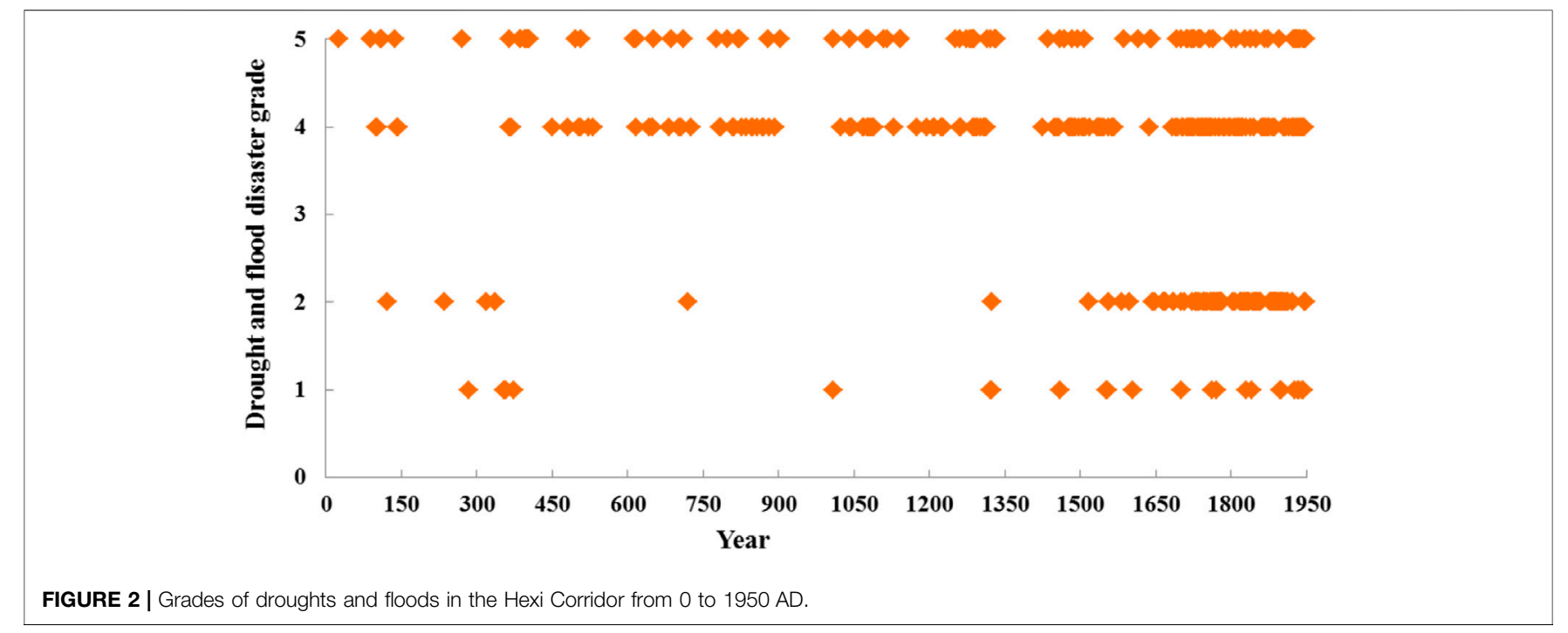

1. Floods occurred once every $17-18$ years on average. The number of droughts and floods increased significantly starting in $300 \mathrm{AD}$. Fluctuations in the occurrence of floods manifested as an increase-decrease-increase pattern. More detailed and accurate records may have been kept in more recent periods. In general, the number of droughts increased continuously, and droughts occurred more frequently than floods in the Hexi Corridor. This result was linked to the location and geographic environment of the area.

\section{Characteristic Changes of Droughts and Floods}

A 10-years moving average was calculated from the reconstructed series to determine long-term variations in droughts and floods.
A peak value analysis showed that droughts occurred frequently in the Hexi Corridor during eight phases, namely, 370-410, $790-870, \quad 1050-1150, \quad 1260-1340, \quad 1430-1570, \quad 1710-1770$, 1800-1890, and 1910-1950. In particular, droughts lasted longer after 1880, with a clear increase in the overall drought duration over time (Figure 3A). Floods occurred frequently during five phases, namely, 320-360, 1670-1710, 1730-1790, $1810-1860$, and 1880-1950. The highest flood frequency among these five phases occurred during the Guangxu period in the Qing Dynasty (Figure 3B). Large fluctuations in the trend line reflected a clear historical increase in the numbers of drought and flood disasters.

We compared the frequencies of droughts and floods over 10year periods to analyze the characteristics in the Hexi Corridor. The two types of disasters were basically the same in terms of the 

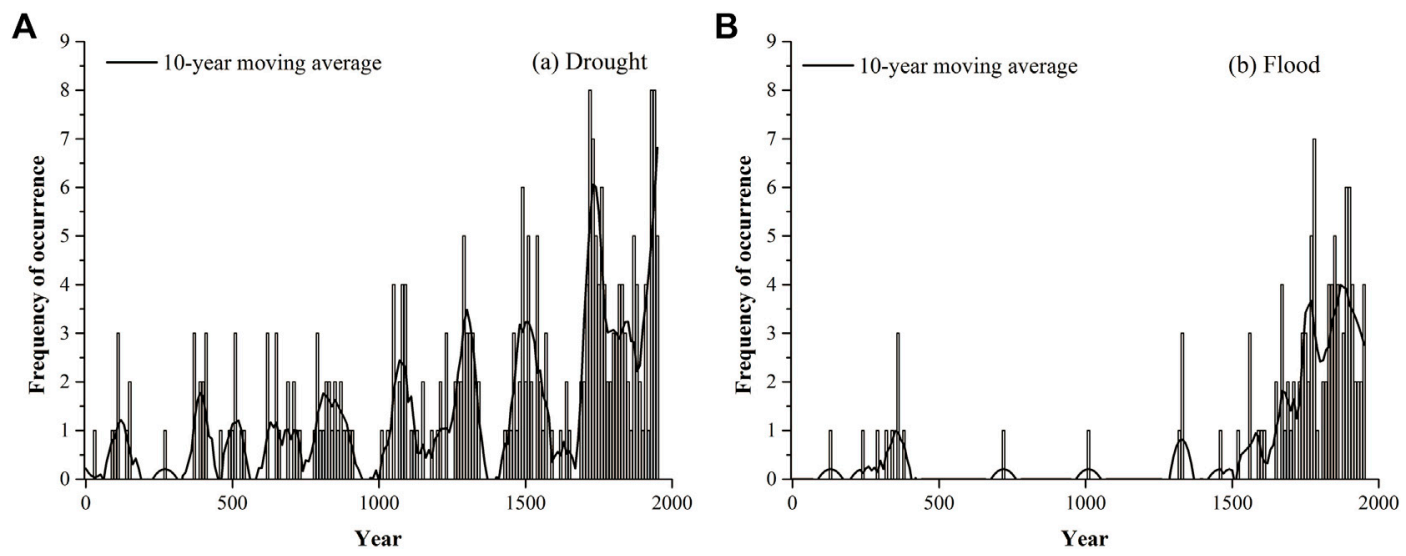

FIGURE 3 | Frequencies of droughts and floods in the Hexi Corridor from 0 to 1950 AD.

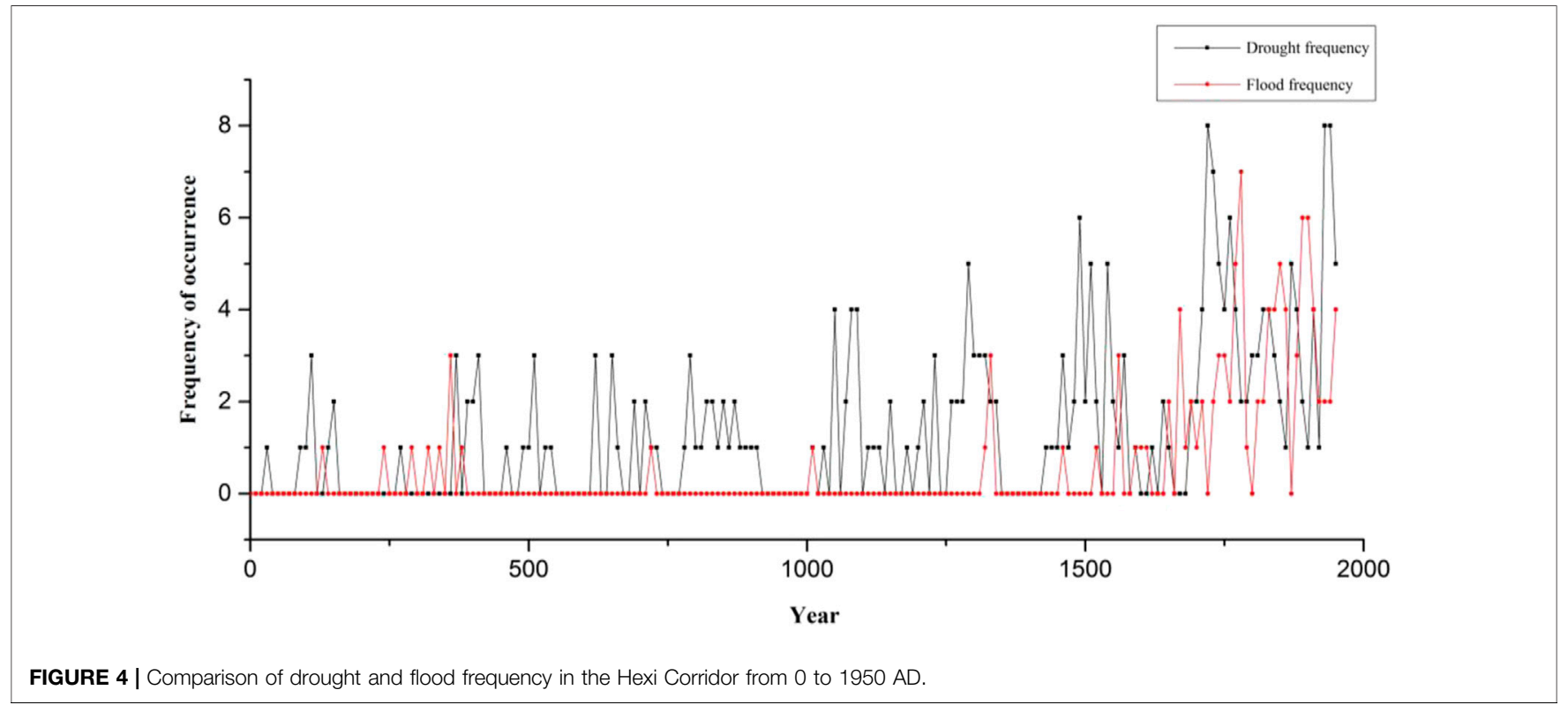

phases of high occurrence and the general trend. The frequencies of droughts and floods have gradually increased over the last 400 years (Figure 4). The results showed that during 1600-1950 AD, drought and flood events occurred 194 times in the Hexi Corridor, and the average frequency was 2.78 years. These events occurred more frequently in the middle and late stages of the study period, and the frequency showed an upward trend. The occurrence of droughts and floods in the Hexi Corridor alternated to some extent, with frequent correspondence in intensity between nearby floods and droughts in the time series. Major droughts were generally followed by major floods. For instance, major droughts lasting for years were followed by major floods at approximately 1720-1780 AD, 1830-1860 AD, and 1900-1940 AD. Considering the full time series showed that droughts occurred more frequently and with higher intensity than floods in the Hexi Corridor.

\section{Periodic Characteristics of Droughts and Floods}

Droughts and floods occurred during different phases with a welldefined periodicity. The Morlet wavelet was used to analyze the historical data of droughts and floods during the 1950-years study 


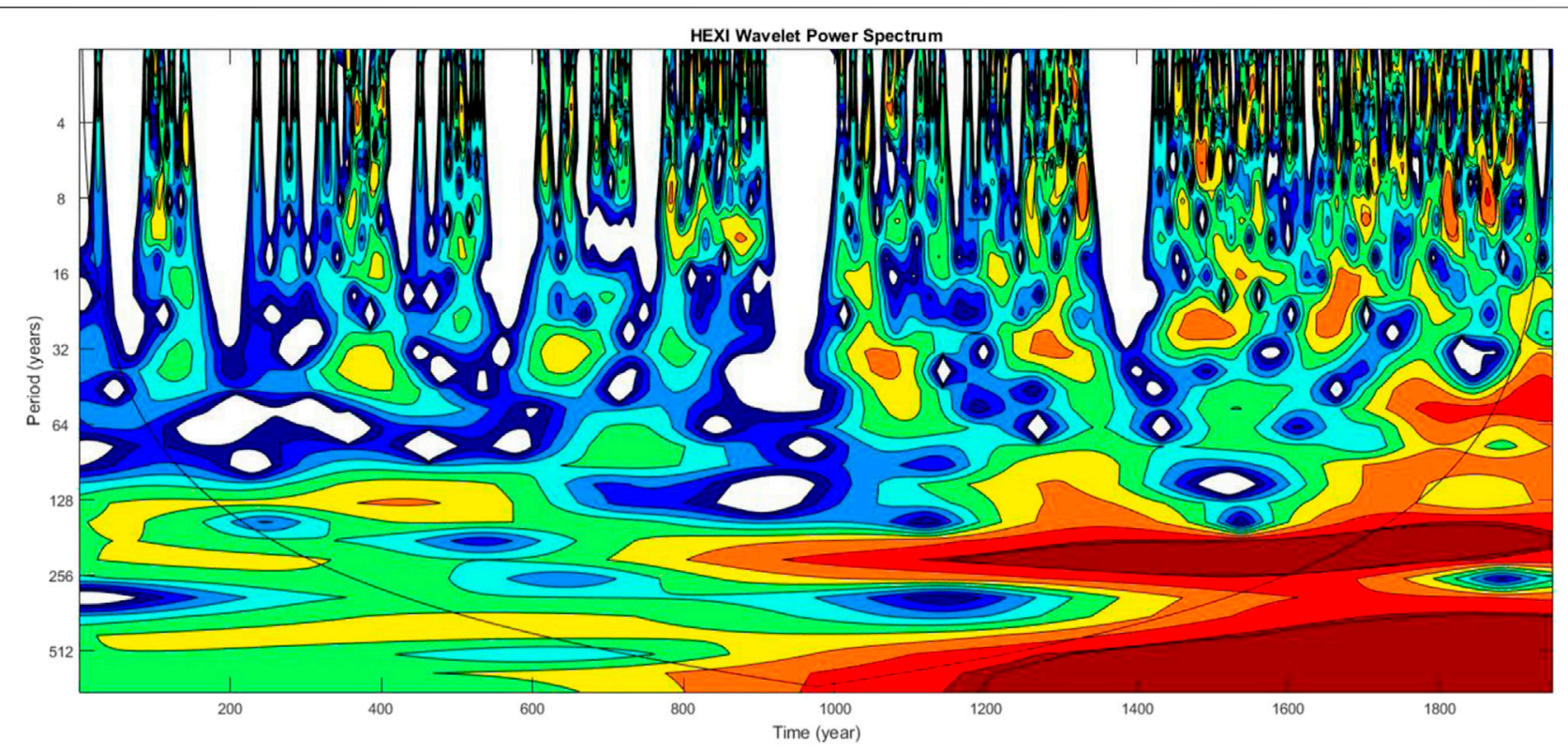

FIGURE 5 | Wavelet analysis of droughts and floods in the Hexi Corridor from 0 to 1950 AD.

period. A wavelet variance analysis (Figure 5) showed that there were 3 oscillation periods at approximately 33-34 a, 71-77 a, and 165-220 a, and the oscillation period around 165-185 a was most intense. Our findings match with the research of $\mathrm{Li}$ and Zhao. (2008), which demonstrated that there was a period around $168 \mathrm{a}$ for the drought and flood disasters in northwestern China.

\section{Relationship Between the Occurrence of Droughts and Floods and Climate Change}

An analysis of the reconstructed drought and flood data shows scarce historical records for the Hexi Corridor in northwestern of China before 1000 AD (the Northern Song Dynasty), such that detailed disaster records were not available. The data from 1000 to 1950 were subsequently used to determine the drought and flood influence factors. Liu et al. (2004) used tree-ring data from the central part of the northern slope of the Qilian Mountains to reconstruct the temperature changes in the Qilian region over a millennial scale. The cold and warm periods in the Qilian juniper tree-ring records match well with the Dunde ice core records and the winter half-year temperature records in eastern China (Thompson et al., 1995; Yao et al., 1996). The results of Liu et al. (2004) were used to classify the cold and warm changes from 1000 to 1950 into eight phases, and the frequencies of droughts and floods were calculated for each phase. The drought frequency was clearly higher during the cold phases than during the warm phases for phases 1 to 6 , whereas the reverse occurred during phases 7 and 8 . There flood frequency was clearly higher during the warm periods than during the cold periods for phases 5 to 8 . However, floods only occurred during the cold phases for phases 1 to 4 (Table 2).

Climate change may have been the main influence factor for the occurrence of droughts and floods before 1580. Note that droughts were more frequent during cold periods than during warm periods, and the flood frequency fluctuated but increased over time. Human activities have caused global climatic deterioration since 1581, coupling with frequent extreme drought and flood events (Table 3). Human activities have significantly changed the spatial pattern of water resources and surface vegetation coverage, which has conspicuously affected the local climate (Zhang et al., 1997). Consequently, droughts and floods have been affected by climate change and indirectly by human activities. Further study is required to determine whether the frequent droughts and floods in the Hexi Corridor resulted from intensified human activities or natural environmental evolution.

\section{Relationship Between the Occurrence of Droughts and Floods and Land Area Change}

The frequencies of droughts and floods per 50 years increased from approximately 2.3 during the Han Dynasty to approximately 43.2 during the Republic of China era over the study period (Table 3). The occurrence of droughts and floods increased continuously throughout the study period. Cheng. (2007) reconstructed the desertified land areas of the Hexi Corridor during the last 2000 years, corresponding to three large-scale desertification processes. The desertified land area during the Northern and Southern Dynasties (420-589 AD), the final Tang and Five Dynasties (836-960), and the Ming and Qing Dynasties (1368-1911 AD) was 1070, 1765, and $6,884 \mathrm{~km}^{2}$, respectively. The changes in the desertified land areas were basically consistent with the occurrences of disasters. The large-scale construction of water conservancy projects and reclamation of oases, have resulted in frequent 
TABLE 2 | Droughts and floods disasters during cold and warm phases from 1000 to 1950.

\begin{tabular}{|c|c|c|c|c|c|c|}
\hline Phase & Year (AD) & $\begin{array}{c}\left.\text { Temperature ( }{ }^{\circ} \mathbf{C}\right) \text { (Liu } \\
\text { et al., 2004) }\end{array}$ & $\begin{array}{l}\text { Period length } \\
\text { (years) }\end{array}$ & $\begin{array}{l}\text { Proportion of drought } \\
\text { frequency }(\%)\end{array}$ & $\begin{array}{l}\text { Proportion of flood } \\
\text { frequency }(\%)\end{array}$ & $\begin{array}{c}\text { Cold and warm periods (Liu } \\
\text { et al., 2004) }\end{array}$ \\
\hline 1 & 1000-1050 & 1.79 & 50 & 15.0 & 2.0 & Cold \\
\hline 2 & $1051-1150$ & 1.92 & 100 & 12.0 & 0.0 & Warm \\
\hline 3 & $1151-1350$ & 1.81 & 200 & 15.5 & 3.0 & Cold \\
\hline 4 & $1351-1440$ & 2.21 & 90 & 2.2 & 0.0 & Warm \\
\hline 5 & $1441-1510$ & 1.8 & 70 & 28.6 & 1.4 & Cold \\
\hline 6 & $1511-1580$ & 1.98 & 70 & 17.1 & 5.7 & Warm \\
\hline 7 & $1581-1890$ & 1.72 & 310 & 26.8 & 21.9 & Cold \\
\hline 8 & 1891-1950 & 2.06 & 59 & 45.8 & 33.9 & warm \\
\hline
\end{tabular}

TABLE 3 | Frequencies of disasters and changes in desertified land area during historical periods.

\begin{tabular}{|c|c|c|c|c|c|c|c|}
\hline Historical periods & Year (AD) & $\begin{array}{c}\text { Flood } \\
\text { frequency }\end{array}$ & $\begin{array}{l}\text { Drought } \\
\text { frequency }\end{array}$ & $\begin{array}{l}\text { Total number of } \\
\text { disasters }\end{array}$ & $\begin{array}{c}\text { Frequency (per } 50 \\
\text { years) }\end{array}$ & $\begin{array}{l}\text { Desertified land } \\
\text { area }\left(\mathbf{k m}^{2}\right)\end{array}$ & $\begin{array}{c}\text { Population ( } 10^{4} \\
\text { Person) }\end{array}$ \\
\hline Han Dynasty & $0-220^{a}$ & 2 & 8 & 10 & 2.3 & - & 28.02 \\
\hline Wei-Jin Era & $220-581$ & 8 & 19 & 27 & 3.8 & 1070 & 19.88 \\
\hline Sui-Tang Dynasty & $581-907$ & 1 & 33 & 34 & 5.2 & 1765 & 27.55 \\
\hline $\begin{array}{l}\text { Song-Yuan Dynasty } \\
\text { (Western Xia) }\end{array}$ & $960-1368$ & 5 & 52 & 57 & 7.0 & - & 10.5 \\
\hline Ming-Qing Dynasty & $1368-1911$ & 83 & 122 & 205 & 18.9 & 6,884 & 30.6 \\
\hline The Republic of China & 1912-1950 & 10 & 22 & 32 & 43.2 & - & 96.5 \\
\hline
\end{tabular}

${ }^{a}$ Note: data for the Eastern and Western Han Dynasties were only available from 0 to $220 A D$, because of limited historical records.

and alternating droughts and floods. In particular, great importance was attached to the development and management of Hexi Corridor during the Ming and Qing Dynasties (Table 3), such that various measures to restore agricultural production were adopted, and inland immigrants were encouraged to expand oasis cultivation (Tang et al., 2018). For example, the population in the Hexi area reached 2.945 million during the Jiaqing period of the Qing Dynasty (1796-1820 AD) (Cheng, 2009). Although the cultivated land area in the Hexi Corridor reached $341,100 \mathrm{hm}^{2}$ at this time, the water conservation system was not complete, and the frequencies of droughts and floods reached 18.9 per 50 years. Thus, disasters occurred in approximately $37.8 \%$ of the years comprising the Qing Dynasty. Historical records from the 40th year of the Qianlong Period of the Qing Dynasty (1775) state "there were droughts, hails, and starving people in 31 sub prefectures, departments, and counties, including Gulang, Fuyi, Zhangye, Dongle, Suzhou, Shandan, Gaotai, and Anxi" and that in Linze County, "because the five canals have been dry for the last several years, people have struggled to survive” (Pan 2009).

\section{DISCUSSION}

Population growth, the development of water and soil resources, cultivated oasis expansion, indiscriminate reclamation, and deforestation resulted in considerable destruction of forest vegetation in the Hexi Corridor. The ecological environment gradually deteriorated, the lands became infertile, and extreme flood and drought events occurred frequently (Li, 2003; Pan 2009; Yu et al., 2011). Compared with the droughts and floods in the historical period, the more recent disasters striking the Hexi Corridor have been more varied, such as climatic droughts, hydrological droughts, ecological droughts, and artificial droughts in recent years. Modern meteorological records show that droughts and floods occurred frequently in the Hexi Corridor in 1956-1995, especially in the middle and lower reaches of the Heihe River (Ren et al., 2010). From 1951 to 2001, there was a considerable proportion of years with consecutive droughts in Zhangye city in the middle reaches of the Heihe River (Yin and Zhang, 2004). The drought proportion was as high as $78.8 \%$ (Chu, 2014). On the background of global warming, the area of irrigated farmland in the Hexi Corridor has increased sharply (Wang and Zhang, 2007), and the amount of agricultural water consumption has gradually increased. These resulted in an average of 60.3 days/year from 1957 to 2000 that the Heihe River dried up (Liu et al., 2008). Intense human activities have greatly changed the natural circulation of water resources in the area, resulting in soil erosion, enhanced desertification, sharp declines in forest and grassland areas, and deterioration of the ecological environment. The frequent occurrence of droughts and floods is further affected by humans. Therefore, the intensity and frequency of human activities should be weakened.

The effect of human activities on droughts and floods, in addition to that of natural evolution, makes the periodicity of droughts and floods more complex. The increasing frequency and intensity of extreme hydrological events has made "two droughts in 3 years" an inescapable reality in the Hexi Corridor (Ke and Lv, 2005). It is necessary to quantify the impacts of natural factors and human activities on the occurrence of droughts and floods in this typical inland arid region the 
future. Special attention should be paid to the hydrological cycle of the Heihe River, Shiyang River, and Shule River in the Hexi Corridor. (For example, March to May is the peak of spring irrigation in the middle reaches of the rivers. This time coincides with the dry season of the rivers, and the downstream riverbeds dry up. July to September is the high-water season of summer. The peak annual runoff is formed in September.) Attention should also be paid to the potential impact of factors such as river channel relocation, land-use changes, and runoff changes at outlets of rivers on extreme hydrological events.

\section{CONCLUSION}

Historical documents were used to reconstruct a series for the occurrence of droughts and floods in the Hexi Corridor from 0 to $1950 \mathrm{AD}$. Wavelet analysis was used to determine the disaster cycle of the series. Considering the changes in the climate (after $1000 \mathrm{AD}$ ) and desertified land area in the region showed that flood and drought disasters were affected by climate change and human activities in the Hexi Corridor. Nevertheless, it is difficult to discriminate between the influence of natural fluctuations and human interventions.

1) Drought was the main influence factor for disasters over time. Droughts occurred more frequently and intensively than floods. Droughts occurred very frequently during eight phases, on average once every seven to 8 years. The drought frequency clearly increased over time. Floods occurred very frequently certain phases, once every 17-18 years on average.

2) Droughts and floods occurred over three distinct periodic lengths, namely, 33-34 a, 71-77 a, and 165-220 a. Comparison with other study that there was a period around 168a for the drought and flood disasters in northwestern China.

\section{REFERENCES}

Abramovich, F., Bailey, T. C., and Sapatinas, T. (2000). Wavelet Analysis and its Statistical Applications. J. R. Statist Soc. D 49 (1), 1-29. doi:10.1111/14679884.00216

Bai, H. Z., Dong, A. X., and Zheng, G. F. (2010). The Atlas of Drought and Flood Distribution over Northwest China in Past 500 years: 1470-2000. Beijing: China Meteorological Press.

Central Meteorological Administration (1981). Yearly Charts of DrynessWetness in China for the Last 500 Years Period. Beijing: Cartographic Publishing House.

Cheng, G. D. (2009). Integrated Management of the Water-Ecology-Economy System in the Heihe River Basin. Beijing: Science Press, 581.

Cheng, H. Y. (2007). Study on Desertification in Hexi Corridor in Historical Period. Lanzhou: Lanzhou University.

Chinese Academy of Meteorological Sciences, China Meteorological Administration (1981). Yearly Charts of Dryness/Wetness in China for the Last 500-Year Period. Beijing, China: SinoMaps Press.

Chu, C. (2014). Analysis on Change Regulation of Meteorological Disasters in Zhangye City during 1980 to 2010. Mod. Agric. Sci. Tech. (3), 258-259.

Dong, A. X., Wang, P. X., and Lin, B. (2005). China Meteorological Disaster Ency-Clopedia: Gansu Fascicule. Beijing: China Meteorological Press, $16-220$.
3) Climate changes appear to have been the main factor affecting droughts and floods before 1580 AD. However, alternation between droughts and floods became more significant after the 16th century because human activities intensified the frequency of disasters. A preliminary analysis shows that changes in the desertified land area were basically consistent with the occurrence of disasters, indicating that overcultivation of oases, indiscriminate reclamation, and deforestation increased the frequency of droughts and floods. Further studies are required to determine whether this phenomenon was caused by human activities or natural environmental evolution.

\section{DATA AVAILABILITY STATEMENT}

The raw data supporting the conclusions of this article will be made available by the authors, without undue reservation.

\section{AUTHOR CONTRIBUTIONS}

XT: conceptualization, methodology, and writing draft. QF: supervision and reviewing.

\section{FUNDING}

This study was funded by the National Natural Science Foundation of China (Grant Nos. 41801079) and the Natural Science Foundation of Gansu Province, China (Grant Nos. 18JR3RA385). The authors would like to thank the editors and reviewers for detailed and constructive comments that significantly improved the manuscript.

Dong, W. M., An, C. B., Zhao, Y. T., and Li, H. (2012). Variation of D/F Records in Historical Documents of Hexi Region during LIA and its Mechanism. Arid Land Geogr. 35 (6), 946-951.

Feng, S. W. (1982). The Organization of Historical Climate Data about Qilian Mountain and Surrounding Areas. Hist. Geogr. Northwest China 1, 1-19.

Field, C., Barros, V., Stocker, T., Qin, D., Dokken, D., Ebi, K., et al. (2012). Managing the Risks of Extreme Events and Disasters to advance Climate Change adaptationSpecial Report of the Intergovernmental Panel on Climate Change Working Group.

Ji, Y., Zhou, G., Wang, S., and Wang, L. (2015). Increase in Flood and Drought Disasters during 1500-2000 in Southwest China. Nat. Hazards 77 (3), 1853-1861. doi:10.1007/s11069-015-1679-9

Ke, Y., and Lv, X. Y. (2005). Focus on Heihe. Beijing: China Water \& Power Press, 72. Kundzewicz, Z. W., and Kaczmarek, Z. (2000). Coping with Hydrological Extremes. Water Int. 25 (1), 66-75. doi:10.1080/02508060008686798

Li, B. C. (2003). Northwest Development and Sustainable Development Series Book: Researches on the Desertification in the Hexi Corridor during Historical Period. Beijing: Science Press.

Li, Y. F., and Zhao, J. B. (2008). The Research on the Flooding Disaster in Guanzhong in Recent 200 Years. Journalof Arid Land Resour. Environ. 22 (4), 96-99.

Liu, W., Wang, T., and Zheng, H. (2008). Driving Forces of Different Type of Land Desertification in Hiehe River Basin. J. Desert Res. 28 (4), 634-641.

Liu, X. H., Qin, D. H., and Shao, X. M. (2004). Temperature Variations Recorded in Tree-Rings of Middle Qilian Mountains during the Last Millennium. Sci. China (Series D) 34 (1), 89-95. 
Lv, Z. X., Wei, Y. P., and Xiao, H. L. (2015). Evolution of the Human-Water Relationships in Heihe River basin in the Past 2000 Years. Hydrol. Earth Syst. Sci. Discuss. 12 (1), 1059-1091.

Pan, C. H. (2009). The Water Conservancy Construction and the Changing of Ecological Environment of the Hexi Corridor in the Qing Dynasty. Agric. Hist. China (4), 123-130.

Pfister, C., and Wanner, H. (2002). Documentary Evidence. PAGES news 10 (3), 2. doi:10.22498/pages.10.3.2

Qian, W., and Zhu, Y. (2002). Little Ice Age Climate Near Beijing, China, Inferred from Historical and Stalagmite Records. Quat. Res. 57, 109-119. doi:10.1006/qres.2001.2283

Ren, C. X., Lu, Y. Q., and Yang, D. Y. (2010). Drought and Flood Disasters and Rebuilding of Precipitation Sequence in Heihe River Basin in the Past 2000 Years. J. Arid Land Resour. Environ. 24 (6), 91-95.

Sang, Y. F., Wang, Z. G., and Liu, C. M. (2013). Applications of Wavelet Analysis to Hydrology: Status and Prospects. Prog. Geogr. 9 (9), 1413-1422.

Tang, X., and Feng, Q. (2015). An Analysis on Historical Process and Driving Mechanism of Land Use Change in Heihe River Basin. Res. Soil Water Conservation 22 (03), 336-340.

Tang, X., Zhang, Z. Q., Wei, Y. P., Xiong, Y. L., and Wang, Q. H. (2014). Quantitative Evaluation of Water Resources Pressure in Heihe River Basin. Bull. Soil Water Conservation 6, 219-224.

Tang, X., Zhao, Y., Zhang, Z., Feng, Q., and Wei, Y. (2018). Cultivated Oasis Evolution in the Heihe River basin over the Past 2,000 Years. Land Degrad. Dev. 29, 2254-2263. doi:10.1002/ldr.2991

Thompson, L. G., Mosley-Thompson, E., Davis, M. E., Lin, P. N., Dai, J., Bolzan, J. F., et al. (1995). A 1000 Year Climate Ice-Core Record from the Guliya Ice Cap, China: its Relationship to Global Climate Variability. A. Glaciology. 21, 175-181. doi:10.1017/s0260305500015780

Sendai: UN Conference Adopts New, People-Centred Disaster Risk Reduction Strategy. (2015) Available at: http://www.un.org/apps/news/story.asp? NewsID $=50361 \&$ Kw1 $=$ Disaster $\&$ Kw2 $=\&$ Kw3 $=\#$. VjrEMYWAKrM.

Wang, H. Q., and Zhang, B. (2007). Driving Force of Drought and the Trend Predication in Heihe River Basin. J. Arid Land Resour. Environ. 21 (9), 68-72.

Wen, K. G., and Dong, A. X. (2005). Encyclopaedia of China's Meteorological Disasters: Gansu Volume. Beijing: China Meteorological Press.

Xiao, S. C., and Xiao, H. L. (2008). Water Balance Assessment and the Lower Reachespwater Regime Processes in Heihe River Basin in the Last 2000 Years. J. Glaciology Geocryology 30 (5), 733-739.

Xing, Z. Q., Yan, D. H., Lu, F., and Ma, H. J. (2013). Advances in the Study of Anthropogenic Effects on the Drought and Flood Events. J. Nat. Resour. 28 (6), 1070-1082.
Yao, T. D., Qin, D. H., and Tian, L. D. (1996). Variations in Temperature and Precipitation in the Past 2000 a on the Xizang (Tibet) Plateau-Guliya Ice Core Record. Sci. China 26 (4), 348-353.

Ye, B. S., Zhao, C. Y., and Jiang, F. Q. (2014). Characteristics of the Flood and Drought Disasters in the Tarim River basin in Recent 300 Years. J. Glaciology Geocryology 36 (1), 173-182.

Yin, X. L., and Zhang, D. Y. (2004). The Drought Characteristics Analysis in Zhangye City in 2001 and Some Defending Countermeasures. Arid Meteorology 22 (3), 38-43.

Yu, K. K., Zhao, J. B., and Luo, D. C. (2011). Preliminary Study on Drought Disasters and Drought Events in the Hexi Corridor in the Ming and. Qing Dynasties 28 (2), 288-293.

Yuan, L. (1994). History of Disaster and Famine in Northwest China. Lanzhou: Gansu People's Publishing House.

Yuan, Z., Yan, D. H., Yang, Z. Y., Yin, J., and Yuan, Y. (2014). Research on Temporal and Spatial Change of $400 \mathrm{Mm}$ and $800 \mathrm{Mm}$ Rainfall Contours of China in 1961-2000. Adv. Water Sci. 25 (4), 494-502.

Zhang, D. E. (2000). A Compendium of Chinese Meteorological Records of the Last 3000 Years. Nanjing: Jiangsu Education Press.

Zhang, P. Y., Ge, Q. S., and Zhang, S. H. (1997). The Modes and Abrupt Changes of Climate in China during Recent 2000 Years. Quat. Res. 1, 12-20.

Zhangye Prefectural Committee (1958). The Chorography of Hexi. Gansu: Zhengye Press.

Zhou, Z. H., and Ma, J. (2018). Spatial-temporal Evolution Mechanism of Historical Towns in Hexi Corridor: Taking Cultural Relics protection Units as an Example. Huazhong Architecture 8, 12-19.

Conflict of Interest: The authors declare that the research was conducted in the absence of any commercial or financial relationships that could be construed as a potential conflict of interest.

Publisher's Note: All claims expressed in this article are solely those of the authors and do not necessarily represent those of their affiliated organizations, or those of the publisher, the editors and the reviewers. Any product that may be evaluated in this article, or claim that may be made by its manufacturer, is not guaranteed or endorsed by the publisher.

Copyright $(2021$ Tang and Feng. This is an open-access article distributed under the terms of the Creative Commons Attribution License (CC BY). The use, distribution or reproduction in other forums is permitted, provided the original author(s) and the copyright owner(s) are credited and that the original publication in this journal is cited, in accordance with accepted academic practice. No use, distribution or reproduction is permitted which does not comply with these terms. 